\title{
Pemberdayaan Masyarakat Pesisir dalam Rangka Pengembangan Desa Ekowisata di Desa Margasari, Kecamatan Labuhan Maringgai, Kabupaten Lampung Timur
}

\author{
Helvi Yanfika*, Puspita Yuliandari \\ Fakultas Pertanian, Universitas Lampung, Bandar Lampung, 35145, Lampung, Indonesia
}

\begin{abstract}
Desa Margasari merupakan desa yang memiliki hutan mangrove dengan paling luas di Provinsi Lampung, sehingga dijadikan sebagai pusat kegiatan pengelolaan hutan mangrove. Sampai saat ini, Pengembangan ekowisata di Desa Margasari masih memiliki kendala terkait dengan pemeliharaan dan pengelolaan hutan mangrove yang biasa sehingga luas hutan mangrove banyak mengalami penurunan. Selain itu, potensi Desa Margasari terkait dengan hasil laut seperti ikan,udang, dan kepiting serta pantainya belum dikembangkan secara optimal dikarenakan terkendala ilmu pengetahuan, SDM dan teknolologi pengolahan hasil laut dan hasil hutan. Oleh karena itu, diperlukan program kegiatan yang dapat mengembangkan Desa Margasari menjadi desa ekowisata bahari. Tujuan pengabdian ini adalah untuk meningkatkan pengetahuan dan keterampilan masyarakat pesisir Desa Margasari: 1) mengenai teknologi dan budidaya pengelolaan hutan mangrove, 2) mengenai pemberdayaan masyarakat pesisir, 3)mengenai kewirausahaan dan teknologi pengolahan hasil laut dan hasil hutan mangrove menjadi produk olahan serta teknik pengemasan dan pemasaran produkolahannya. Tahap Persiapan Penyediaan Materi, Kegiatan Penyuluhan, Tahap Pembimbingan, Tahap Pendampingan, dan Tahap Evaluasi. Hasil dari kegiatan ini adalah meningkatnya pengetahuan, pemahaman, dan keterampilan peserta dalam pengelolaan dan pengembangan ekowisata berbasis pemberdayaan masyarakat.
\end{abstract}

Keywords: Ekowisata, Hutan, Mangrove, Pengetahuan

\section{Pendahuluan}

Kecamatan Labuhan Maringgai merupakan salah satu kecamatan yang berada di Kabupaten Lampung Timur yang merupakan dataran dengan ketinggian rata-rata 7 meter di atas permukaan laut dengan luas wilayah 142, $65 \mathrm{~km}^{2}$ [1]. Berdasarkan posisi geografisnya, Kecamatan Labuhan Maringgai memiliki batas-batas wilayahnya berbatasan dengan Kecamatan Braja dan Taman Nasional Way Kambas di sebelah Utara, Kecamatan Pasir Sakti dan Gunung Pelindung di sebelah selatan, lautan jawa di sebelah timur dan

\section{* Corresponding author: helviyanfika81@gmail.com}

Received 20 October 2021; Received in revised form 30 October 2021; Accepted 3 November 2021 Available online 29 December 2021

Lembaga Penelitian dan Pengabdian Kepada Masyarakat

Universitas Lampung 
Kecamatan melinting, Bandar sribawono dan mataram bari di sebelah barat.

Menurut BPS Provinsi Lampung (2015), Kabupaten Lampung Timur merupakan wilayah terluas di Provinsi Lampung, sedangkan untuk jumlah kecamatan yang dimiliki menempati posisi kedua setelah Kabupaten Lampung Tengah, Kabupaten Lampung Timur merupakan salah satu kabupaten yang memiliki wilayah pesisir yang terluas di Provinsi Lampung karena dilalui oleh garis pantai timur. Wilayah pesisir yang memiliki luas wilayah pesisir terbesar yaitu wilayah pantai timur. Wilayah pesisir yang memiliki luas wilayah pesisir terbesar yaitu wilayah pantai timur dengan luas 270.000 ha [2]. Wilayah tersebut mencakup wilayah dari Kabupaten Lampung Selatan, Kabupaten Lampung Timur sampai dengan Kabupaten Tulang Bawang. Wilayah pantai timur atau pesisir timur melintasi Kabupaten Lampung Timur yang meliputi Kecamatan Sukadana, Way Kambas, Labuhan Maringgai, Pasir Sakti, Way Bungur, dan Way Jepara [3].

Salah satu desa yang ada di Kecamatan Labuhan Maringgai yaitu Desa Margasari memiliki luas wilayah 1.702 ha atau sebesar 11,93\% dari keseluruhan luas di Kecamatan Labuhan Maringgai yang terdiri dari wilayah permukiman, persawahan, perkebunan, kuburan, pekarangan dan prasarana umum lainnya. Desa Margasari juga merupakan salah satu desa yang berbatasan langsung dengan pantaitimur atau pesisir timur, desa tersebut memiliki hutan mangrove yang digunakan untuk menjaga terjadinya abrasi. Desa Margasari merupakan desa yang memiliki luas hutan mangrove yang paling luas sehingga dijadikan sebagai pusat kegiatan pengelolaan hutan mangrove.

Pada saat ini, pemerintah Desa Margasari sedang fokus terhadap penanganan dan pengelolaan hutan mangrove dan desa ekowisata bahari di Pantai Lampung Mangrove Center. Tanaman mangrove sebagai tanaman yang mengelilingi pantai difungsikan sebagai objek wisata yang menjadi daya Tarik pengunjung dengan dibangunnya jembatan dari bambo.

Potensi Desa Margasari juga sangat besar dikarenakan terdapat Kelompok Tani Hutan (KTH) yang merupakan wadah masyarakat pesisir untuntuk mengembangkan dan mengelola potensi desa dan hutan mangrove. Adapun KTH yang adai di Desa Margasari antara lain yaitu KTH Sekar Bahari, KTH Lestari Indah, Benteng Pesisir, KTH Benteng Timur, KTH Hijau Mekar, KTH Layan Pandang dan KTH Marga Jaya.

Sampai saat ini, pengembangan ekowisata di Desa Margasari masih memiliki kendala terkait dengan pemeliharaan dan pengelolaan hutan mangrove yang biasa dikenal dengan nama Lampung Mangrove Center (LMC). LMC sendiri berdiri dilatarbelakangi terjadinya kerusakan hutan mangrove sebagai sabuk hijau (green belt) di pesisir timur Lampung yang sudah memprihatinkan. Kerusakan hutan mangrove membuat beberapa pihak khususnya masyarakat Desa Margasari dibantu oleh berbagai pihak antara lain Pemerintah Kabupaten Lampung Timur dan stakeholders yang terdiri dari Universitas Lampung dan Lembaga Swadaya Masyarakat dalam melestarikan kawasan hutan mangrove. Desa Margasari merupakan desa yang banyak mengalami penurunan luas hutan mangrove. Selain itu, potensi Desa Margasari terkait dengan hasil laut seperti ikan, udang, dan kepiting serta pantainya belum dikembangkan secara optimal dikarenakan terkendala ilmu pengetahuan, Sumber Daya Manusia (SDM) dan teknolologi pengelolaan, budidaya, pengolahan, dan pemanfaatan potensi desa. Oleh karena itu, diperlukan program kegiatan yang dapat mengembangkan Desa Margasari menjadi desa ekowisata bahari [4].

Kegiatan pengabdian masyarakat ini bertujuan untuk 1) Meningkatkan pengetahuan dan keterampilan masyarakat pesisir Desa Margasari Kecamatan Labuhan Maringgai 
Kabupaten Lampung Timur mengenai teknologi dan budidaya pengelolaan hutan mangrove terkait dengan pembelajaran tentang fungsi-fungsinya, baik secara ekologis, ekonomis maupun sosial; keragaman tanaman mangrove; jenis ikan; invertebrata bahkan jenis burung meningkatkan daya tariknya sebagai tujuan ekowisata. 2) Meningkatkan pengetahuan dan keterampilan masyarakat pesisir Desa Margasari Kecamatan Labuhan Maringgai Kabupaten Lampung Timur mengenai pemberdayaan masyarakat terkait pemberdayaan masyarakat pesisir terkait dengan pengelolaan objek wisata bahari dan desa ekowisata berbasis teknologi dalam bentuk publikasi dan promosi objek wisata bahari dan desa ekowisata serta pelatihan masyarakat setempat untuk menjadi pemandu wisata yang dapat memberikan pengetahuan dan pengalaman pengunjung wisata untuk sadar dan lebih menghargai alam serta budaya masyarakat setempat. 3) Meningkatkan pengetahuan dan keterampilan Desa Margasari Kecamatan Labuhan Maringgai Kabupaten Lampung Timur mengenai kewirausahaan dan teknologi pengolahan hasil laut dan hasil hutan mangrove menjadi produk olahan serta teknik pengemasan dan pemasaran produk olahannya.

\section{Metode Pelaksanaan}

Kegiatan yang dilakukan dalam pengabdian kepada masyarakat adalah upaya mengatasi permasalahan pokok mitra, yaitu melalui peningkatan pengetahuan dan kemampuan teknis pariwisata berbasis masyarakat dengan produk utama ekowisata. Transfer iptek untuk meningkatkan kemampuan teknis mitra dilakukan melalui pendekatan praktik belajar dan berbuat (learning by doing), yaitu melalui pelatihan terpadu dan praktik yang bersifat partisipatif di bawah supervisi dan diikuti dengan pendampingan oleh pelaksana kegiatan.

\subsection{Metode Kegiatan}

Meteode yang digunakan dalam kegiatan ini yaitu metode penyuluhan partisipasi, Metode Focus Group Disscussion (FGD), Metode Pelatihan (Demonstrasi dan Kegiatan Praktik oleh Peserta), dan Metode Pembimbingan dan Pendampingan Peserta oleh Tim Pelaksana. Metode penyuluhan partisipasi dengan cara pertemuan rutin yang dilakukan dalam bentuk ceramah dan diskusi di tingkat Kelompok Tani Hutan, BUMDes yang dibentuk olehaparatur desa dan tokoh masyarakat. Metode Focus Group Disscussion (FGD) adalah melakukan dialog aktif dalam kelompok-kelompok kecil antara masyarakat dengan fasilitator untuk menginvestigasi permasalahan lokal yang berkaitan dengan pengelolaan hutan mangrove, pengelolaan pantai untuk menjadi objek wisata bahari berbasis masyarakat dengan produk utama ekowisata dan pemanfaatan potensi desa, hasil laut, dan hasil hutan mangrove menjadi peluang usaha. Metode Pelatihan (Demonstrasi dan Kegiatan Praktik oleh Peserta) merupakan kegiatan pelatihan yang meliputi kegiatan demonstrasi dan kegiatan praktik yang dilakukan sebagai upaya transfer ilmu pengetahuan dan teknologi dengan peserta adalah anggota kelompok tani hutan, karang taruna, komunitas ibu dan penggerak PKK, dan masyarakat sekitar. Metode Pembimbingan dan Pendampingan Peserta oleh Tim Pelaksana merupakan kegiatan yang dilakukan dengan pendekatan kelembagaan, yaitu proses pembimbingan dan pendampingan yang terus menerus kepada anggota kelompok tani hutan, karang taruna, komunitas ibu dan penggerak PKK, dan masyarakat sekitar [5-7].

\subsection{Tahapan Pelaksanaan Kegiatan}

Tahapan pelaksanaan dalam kegiatan ini meliputi tahap Persiapan Awal dengan Based Line Survey, Tahap Penggalangan Grup Target (Kelompok Sasaran), tahap persiapan penyediaan materi, kegiatan penyuluhan, tahap pelatihan dalam bentuk demonstrasi dan praktik, tahap pembimbingan, tahap pendampingan, dan tahap evaluasi. 


\subsection{Partisipasi Mitra}

Keterlibatan mitra yaitu masyarakat dan KTH Desa Margasari Kecamatan Labuhan Maringgai Kabupaten Lampung Timur dilakukan sejak tahap awal hingga akhir kegiatan pengabdian dilaksanakan meliputi dari tahapan persiapan yang terdiri atas analisis kebutuhan dan analisis pencarian kegiatan, tahapan sosialisasi kegiatan bersifat penyuluhan dan pendekatan, tahapan pelatihan dengan tujuan menambahkan pengetahuan dan keterampilan, dan evaluasi kegiatan yang bersifat mengetahui sejauh mana pemahaman masyarakat dan KTH Desa Margasari Kecamatan Labuhan Maringgai Kabupaten Lampung Timur terhadap pembinaan dan pemberdayaan yang telah disampaikan.

\section{Hasil dan Pembahasan}

\subsection{Kondisi Wilayah}

\subsubsection{Demografi}

Daerah fokus penelitian berada di Kecamatan Labuhan Maringgai, Kabupaten Lampung Timur, yaitu Desa Margasari. Pemilihan lokasi didasarkan pada lokasi Desa Margasari berada di dekat laut dan dilewati oleh beberapa sungai besar di Kecamatan Labuhan Maringgai. Lokasi penelitian Desa Margasari memiliki luas $17,02 \mathrm{~km}^{2}$. Penduduk yang tinggal di Desa Margasari berjumlah 8.784 Jiwa, dengan kepadatan penduduk sebesar 516 Jiwa/ $/ \mathrm{Km}^{2}$. Jumlah laki-laki sebanyak 4.631 Jiwa dan Perempuan sebanyak 4.153 Jiwa. Desa Margasari memiliki suku dominan para penduduk yakni Suku Jawa dan Sunda. Hal ini karena banyak penduduk yang berasal dari Pulau Jawa migrasi ke sebrang pulau untuk mencari pekerjaan dan mengharapkan kehidupan yang lebih baik lagi.

\subsubsection{Fasilitas umum}

Fasilitas umum merupakan sarana yang tersedia untuk kepentingan umum yang diadakan oleh pemerintah atau pihak swasta yang dapat dimanfaatkan oleh masyarakat umum dalam lingkungan pemukiman. Contoh dari fasilitas umum adalah puskesmas, klinik, sekolah, tempat ibadah, pasar, tempat, makam, jalan, angkutan umum, saluran air, jembatan, jaringan listrik, tempat pembuangan sampah, dan lain sebagainya. Fasilitas yang terdapat di Desa Margasari, Kecamatan Labuhan Maringgai, Kabupaten Lampung Timur antara lain:

\subsubsection{Balai desa}

Balai desa merupakan sebuah bangunan milik desa yang menjadi tempat berkumpul warga desa saat mengadakan musyawarah ataupun pertemuan. Keberadaan balai desa penting untuk menunjang kebutuhan desa dalam melaksanakan sebuah kegiatan dengan masyarakat desa. Di Desa Margasari balai desa berdiri kokoh dan dalam keadaan baik yang dapat dilihat pada gambar berikut. 


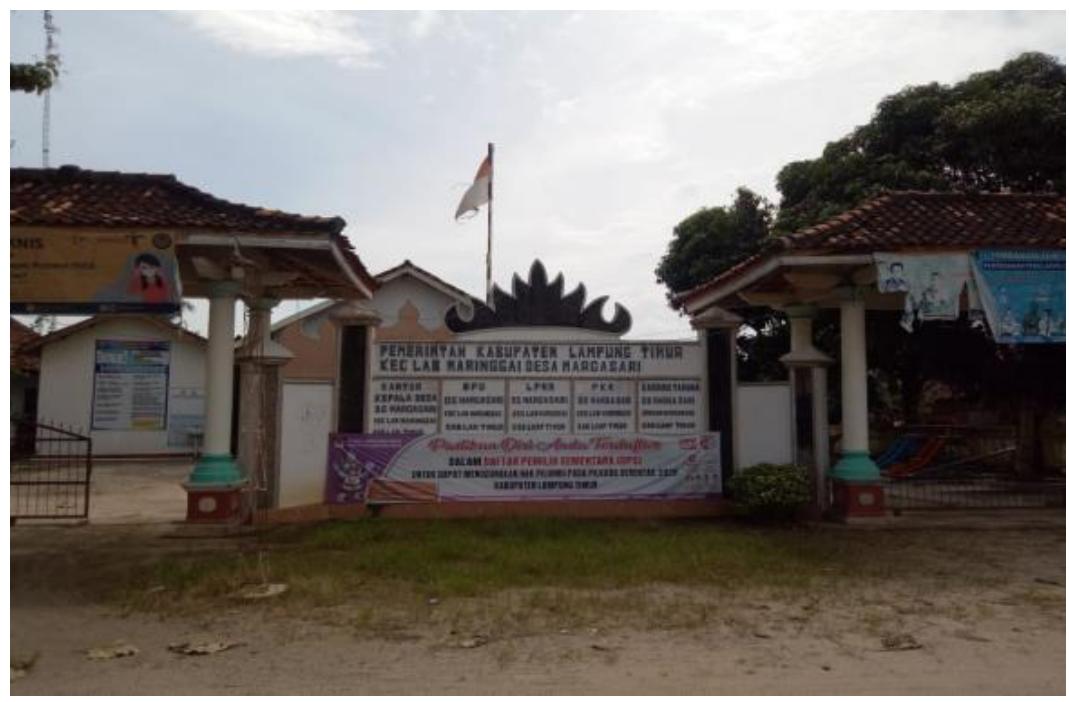

Gambar 1. Balai Desa Margasari

\subsubsection{Fasilitas pendidikan}

Fasilitas pendidikan merupakan segala sesuatu yang dapat memfasilitasi dan memberikan kemudahan dalam menyelenggarakan kegiatan pendidikan. Pendidikan merupakan wahana dan media efektif untuk mengajarkan norma, mensosialisasikan nilai, dan menanamkan etos kerja dikalangan warga masyarakat". Melalui pendidikan diharapkan setiap warga negara memiliki perilaku yang baik sesuai norma dan memiliki etos kerja yang tinggi dan profesional. Fasilitas pendidikan di Desa Margasari terdapat sebanyak 3 Taman Kanak-kanak (TK), 5 Sekolah Dasar (SD), dan 3 Sekolah Menengah Pertama (SMP), sedangkan pada jenang pendidikan Sekolah Menegah Atas (SMA) belum tersedia. fasilitas pendidikan di desa dalam keadaan baik dan terawatt. Berikut ini adalah gambar fasilitas pendidikan di Desa Margasari.

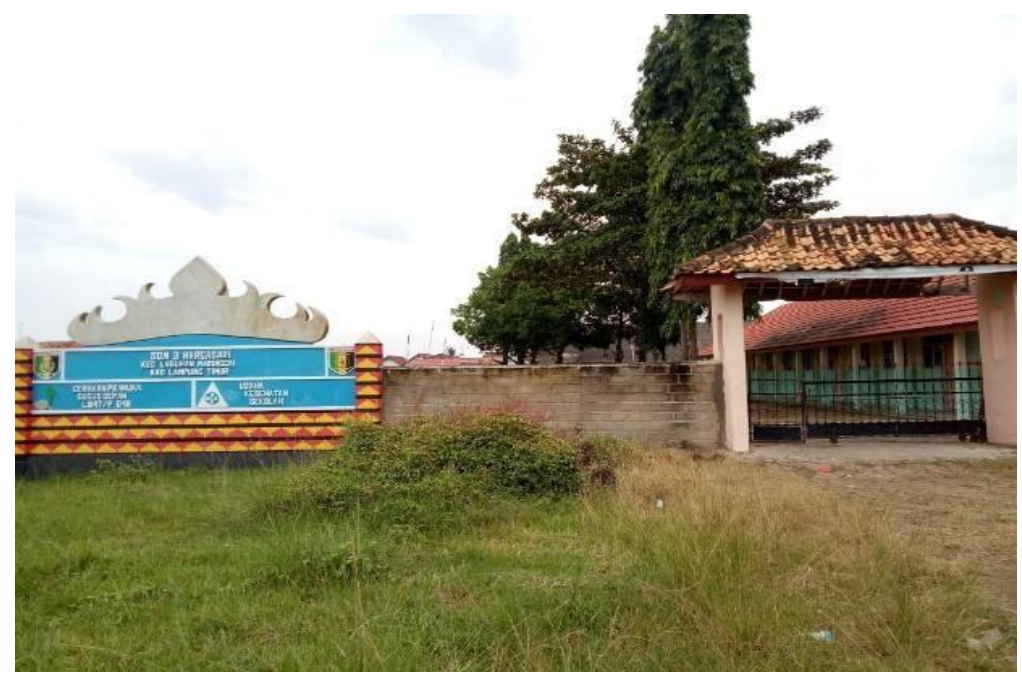

Gambar 2. Fasilitas Pendidikan di Desa Margasari

\subsubsection{Fasilitas Kesehatan}

Fasilitas kesehatan merupakan sebuah sarana yang dapat disediakan dan dikelola oleh pemerintah maupun swasta, bertujuan untuk memberikan pelayanan kesehatan bagi masyaraka. Keberadaan fasilitas kesehatan di Desa Margasari terbilang cukup lengkap. Desa Margasari memiliki 1 Puskesman, 1 Praktik Dokter, 3 Bidan, 1 Poskesdes, 5 Posyanduu, dan 3 Apotek. Keberadaan fasilitas kesehatan diharpkan dapat menjamin 
kesehatan masyarakatnya. Berikut ini adalah gambar fasilitas Kesehatan di Desa Margasari.

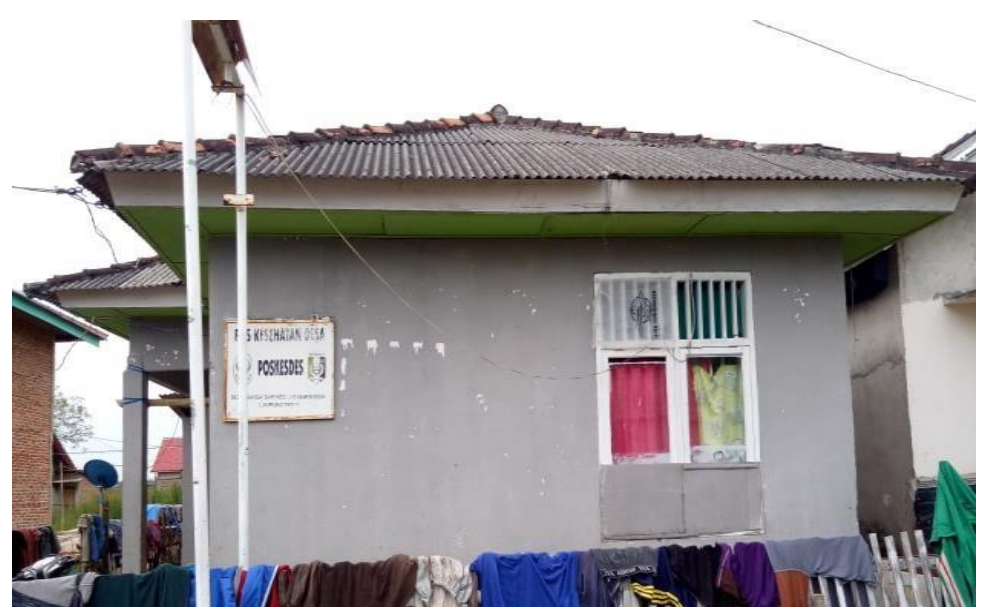

Gambar 3. Fasilitas Poskesdes di Desa Margasari

\subsubsection{Fasilitas Keagamaan}

Keberadaan fasilitas keagamaan penting dalam menunjang kegiatan beribadah masyarakat. Mayoritas masyarakat yang di Desa Margasari beragama Islam sehingga ditunjang dengan keberadaan banyaknya masjid serta mushola disetiap desa. Desa Margasari memiliki 8 masjid, 25 mushola, dan 1 Gereja. Berikut ini gambar fasilitas keagaamaan di Desa Margasari.

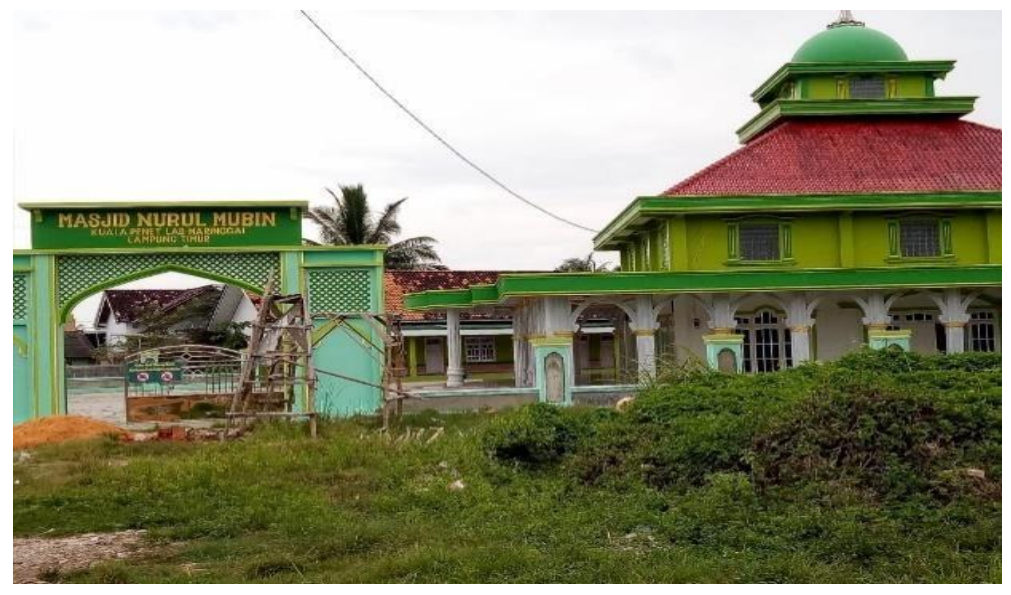

Gambar 4. Keberadaan Masjid di Desa Margasari

\subsubsection{Fasilitas Jalan (Akses Wilayah)}

Berdasarkan pengamatan yang dilakukan di lapangan, didapatkan bahwa kondisi jalan jalur utama yang menghubungkan desa ke desa dalam kondisi baik yaitu jalan beraspal, sehingga mempermudah akses jalan bagi masyarakat sekitar untuk dapat melewati desa. 


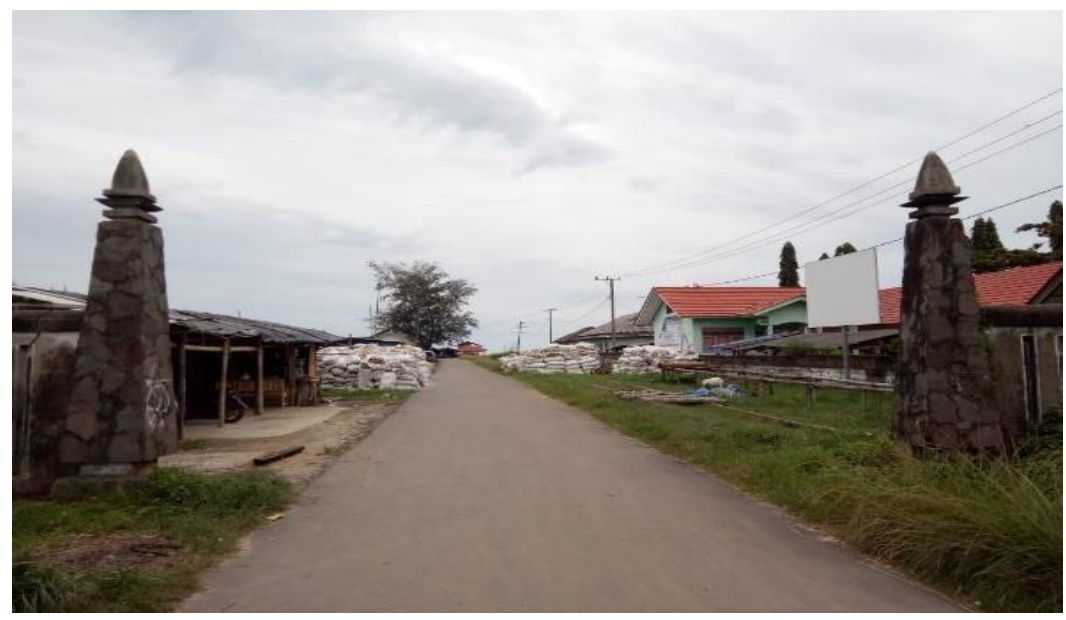

Gambar 5. Keadaan Jalan Utama di Desa Margasari

\subsubsection{Lembaga Ekonomi}

Lembaga ekonomi adalah suatu lembaga yang memiliki kegiatan di bidang ekonomi demi terpenuhinya kebutuhan masyarakat. Adapun contoh dari lembaga ekonomi, diantaranya seperti; lembaga keuangan yang bergerak dibidang menyediakan jasa keuangan untuk nasabah ataupun masyarakat yaitu bank dan koperasi. Lembaga ekonomi lainnya yang berguna untuk memenuhi kebutuhan masyarakat adalah pasar dan toko. Beberapa Lembaga ekonomi yang terdapat di Desa Margasari meliputi; 1 Koperasi, 2 Pasar, dan 135 Toko. Lembaga-lembaga tersebut sangat membantu masyarakat dalam memenuhi kebutuhan sehari-hari. Berikut adalah gambar lembaga ekonomi di Desa Margasari.

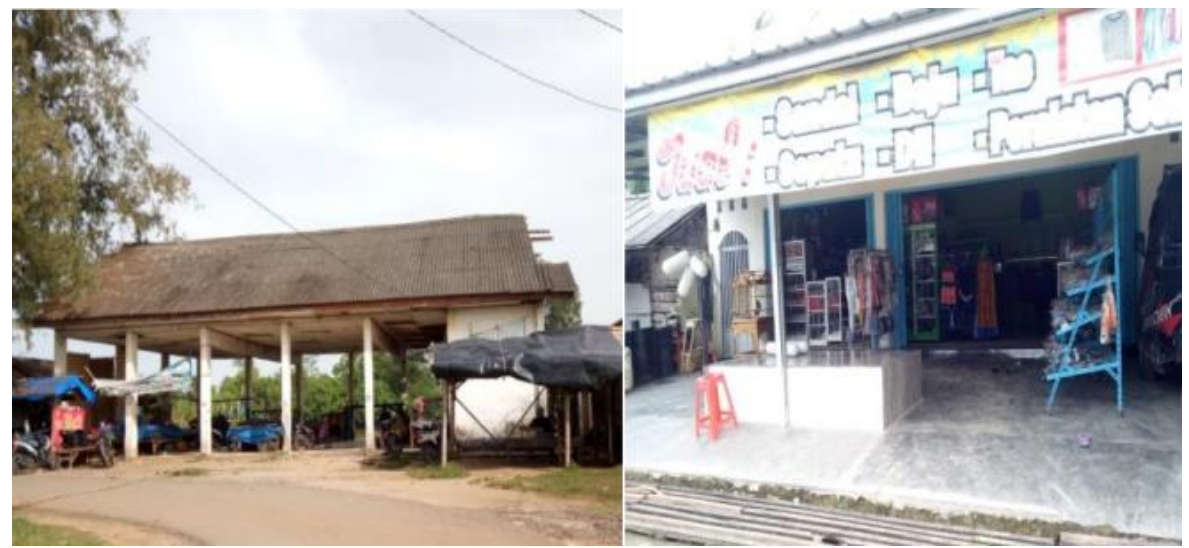

Gambar 6. Keberadaan Lembaga Ekonomi di Desa Margasari

\subsubsection{Sumber Air dan Sanitasi}

Pengamatan yang dilakukan di sekitar lokasi penelitian di Desa Margasari dalam kawasan mangrove memiliki kualitas air yang kurang baik, disebabkan pada daerah ini dikelilingi oleh tambak udang, sungai, dan laut sehingga air tercemar dari laut dan tambak yang menyebabkan sanitrasi air di tanah terganggu. Masyarakat di sekitar pinggiran laut dan tambak memakai air untuk masak dan minum dengan membeli air bersih dalam kemasan galon. 


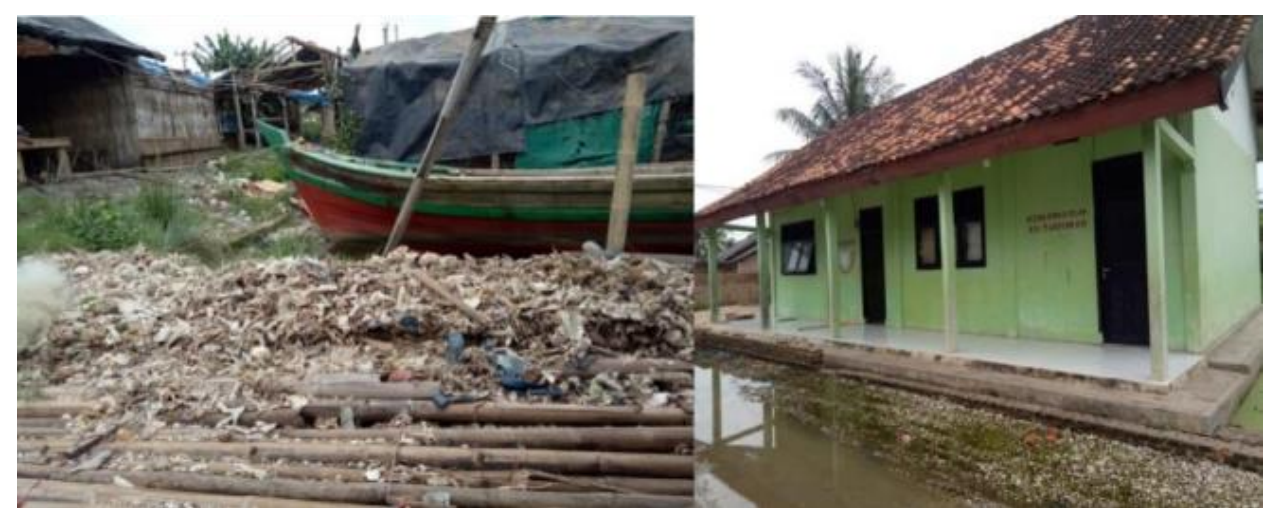

Gambar 7. Lingkungan pinggir laut

Lingkungan di pinggir laut memiliki lingkungan yang kumuh dan tidak sehat, Hal ini dapat dilihat pada gambar dibawah menunjukkan lingkungan tercemar oleh sampah dari hasil laut seperti kerang dan kepiting yang dibuang dengan sembarangnya dikarenakan tidak adanya tempat pembuangan sampah sehingga menjadi pencemaran lingkungan dan mengakibatkan kualitas air terganggu. Rata- rata sumber air bersih yang diperoleh dari sumber gali dengan kategori $85 \%$ dengan akses yang mudah.

\subsection{Hasil Pre-test Pengetahuan dan Pemahaman Peserta}

Kegiatan pengabdian mengenai pemeberdayaan masyarakat pesisir dalam rangka pengembangan desa ekowisata di Desa Margasari, Kecamatan Labuhan Maringgai dilakukan dengan tujuan meningkatkan pengetahuan dan keterampilan dalam pengembangan ekowisata, serta kesejahahteraan masyarakat. Cara mengetahui adanya perubahan pemahaman dan pengetahuan para peserta maka dilakukan pre- test dan posttest. Peningkatan atau perubahan pengetahuan dan pemahaman permasalahan tersebut tercermin dari selisih antara rataan nilai post-test dikurangi dengan rataan nilai pre-test. Untuk menentukan nilai tersebut, berikut hasil nilai pre-test para peserta di Desa Margasari, Kecamatan Labuhan Maringgai.

Materi pre-test dipersiapkan sesuai dengan materi yang telah diberikan selama kegiatan berlangsung oleh narasumber, dengan mempertimbangkan keterbatsan waktu dan kemampuan peserta. Hasil pre-test dapat menjadi gambaran umum awal pengetahuan dan pemahaman dasar peserta terhadap seluruh materi yang diberikan. Secara rinci hasil pretest dijabarkan pada tabel di atas. Secara rata-rata pengetahuan dan pemahaman peserta mengenai pemberdayaan masyarakat dan ekowisata termasuk dalam kategori rendang dengan nilai rata-rata $59,2 \%$, dengan simpulan bahwa:

1. Pengetahuan dan pemahaman peserta dalam keberadaan dan prinsip ekowisata masih rendah

2. Pengetahuan peserta terhadap manajemen pengelolaan ekosistem masih rendah

3. Pengetahuan akan pemberdayaan masyarakat dan tujuannya masih rendah

4. Pengetahuan manajemen keuangan dan akuntansi bagi pengelolaan ekowisata masih rendah

Keadaan ini adalah gambaran bahwa penyuluhan dan pelatihan teknis oleh pihak luar kepada masyarakat pesisir akan pengembangan ekowisata dan manfaat ekowisata masih sangat diperlukan, sehingga dengan adanya kegiatan pengabdian kepada masyarakat ini nantinya diharapkan para peserta dapat menyebarluaskan pengetahuan dan menerapkan terkait pemberdayaan masyarakat berbasis ekowisata. 


\subsection{Hasil Post-test Kemampuan Peserta}

Perubahan atau peningkatan pemahaman peserta terhadap materi melalui pemberian pre-test dan post-test. Materi post-test dipersiapkan sesuai dengan materi yang diberikan oleh narasumber yang berisikan pertanyaan yang sama dengan materi pre-test. Hasil posttest merupakan gambaran umum pemahaman responden terhadap materi setelah dilakukan kegiatan. Nilai yang diperoleh akan dijadikan bahan evaluasi atau tolak ukur sementara terkait pelaksanaan pelatiha yang dieberikan kepada peserta. Tingkat pentingnya pelaksanaan pre post yang kemudian ditutup dengan post-test dalam sebuah kegiatan pelatihan ataupun penyuluhan dapat menunjukkan secara langsung pengaruh baik yang dirasakan oleh peserta, selain peningkatan pemahan akan materi, peserta dan pemateri/penyuluh akan menjalin hubungan emosional seperti kepercayaan dalam meningktakan tujuan peningkatan pelaksanaan budidaya ikan rata-rata kegiatan pengabdian kepada masyarakat dalam pemberdayaan masyarakat pesisir dalam rangka pengembangan desa ekowisata di Desa Margasari, Kecamatan Labuhan Maringgai, Kabupaten Lampung Timur mengalami peningkatan menjadi 70,4\% . Hasil post-test ini bila dibandingkan dengan hasil pre-test, maka peningkatan pemahaman materi oleh peserta selama penyuluhan ini didukung oleh beberapa hal:

1. Metode pembelajaran oleh pemateri dikemas cukup praktis, interaktif sehingga tidak membosankan

2. Materi yang dijelaskan secara singkat dan bermanfaat besar

3. Pengaturan waktu pembelajaran yang efisien dan fleksibel.

4. Keberadaan dukungan yang dapat memperlancar kegiatan pelatiahan mampu menunjukkan peningktatan.

Pelaksanaan pelatihan ini terdapat peningkatan dalam hal:

1. Pengetahuan dan pemahaman peserta dalam keberadaan dan prinsip ekowisata

2. Pengetahuan peserta terhadap manajemen pengelolaan ekowisata dan strategi pengelolaan

3. Pengetahuan akan langkah pemberdayaan masyarakat Desa Margasari, Kecamatan Labuhan Maringgai

4. Pengetahuan mengenai manajemen keuangan dan akuntansi bagi pengelolaan ekowisata

\section{Simpulan}

Kegiatan pengabdian kepada masyarakat pada pemberdayaan masyarakat pesisir dalam rangka pengembangan Desa Ekowista di Desa Margasari Kecamatan Labuhan Maringgai, Kabupaten Lampung Timur dapat disimpulkan bahwa melalui kegiatan ini pengetahuan dan pemahaman meningkat terkait: Pengetahuan dan pemahaman peserta dalam keberadaan dan prinsip ekowisata. Pengetahuan peserta terhadap manajemen pengelolaan ekowisata dan strategi pengelolaan ekowisata khususnya tanaman mangrove. Pengetahuan akan langkah pemberdayaan masyarakat Desa Margasari, Kecamatan Labuhan Maringgai. Pengetahuan mengenai manajemen keuangan dan akuntansi bagi pengelolaan ekowisata.

\section{Daftar Pustaka}

[1] BPS Kecamatan Labuhan Maringgai. (2018). Kabupaten Lampung Timur dalam Angka 2018. Kabupaten Lampung Timur: PBS.

[2] BPS Provinsi Lampung. (2015). Lampung dalam Angka 2015. Provinsi Lampung: BPS. 
[3] Amelia, S., Nurmayasari, I., \& Viantimala, B. (2020). Faktor-Faktor Yang Berhubungan Dengan Partisipasi Masyarakat Dalam Program Lampung Mangrove Center (Lmc) Di Desa Margasari Kecamatan Labuhan Maringgai Kabupaten Lampung Timur. Jurnal IImu Ilmu Agribisnis: Journal of Agribusiness Science, 8(2), 218-225.

[4] Arida, S. (2009). Meretas jalan ekowisata Bali: proses pengembangan, partisipasi lokal, dan tantangan ekowisata di tiga desa kuno Bali. Udayana University Press.

[5] Scheyvens, R. (2000). Promoting women's empowerment through involvement in ecotourism: Experiences from the Third World. Journal of sustainable tourism, 8(3), 232-249.

[6] Supriatna, J. (2010). Peran Kearifan Lokal dalam pelestarian Lingkungan. Jakarta: UI.

[7] Theresia, A. (2015). Pembangunan Berbasis Msyarakat. Bandung: Alfabeta. 